точным индексом артериального давления, что может использоватся в качестве диагностических критериев неблагоприятного течения эссенциальной гипертензии.

Ключевые слова: эссенциальная гипертензия, микроциркуляция, центральное венозное давление.

\title{
THE CONDITION OF THE MICROCIRCULATORY CHANNEL OF THE 'NAIL BED OF THE UPPER EXTREMITIES AND CHANGES OF CENTRAL VENOUS PRESSURE IN PATIENTS WITH THE SECOND STAGE OF ESSENTIAL HYPERTENSION DEPENDING ON THE STRUCTURE OF THE DIURNAL RHYTHM OF ARTERIAL PRESSURE
}

\section{I.A. Plesh, L.I. Haidych}

\begin{abstract}
The peculiarities of changes of the microcirculation of the nail-bed and central venous pressure (CVP) have been presented in the poper in patients the with $2^{\text {nd }}$ stage of essential hypertension depending on different variants of the circadian rhythm of arterial pressure. An inverse interdependence has been established between the level and a decrease of the specific gravity of the functioning capillaries in the patients with a low (non-dipper) and negative (night-picker) diurnal index of arterial pressure that con be used as diagnostic criteria of a high risk of possible complications of essential hypertension.
\end{abstract}

Key words: essential hypertension, microcirculation, central venous pressure.

Bukovinian State Medical University (Chernivtsi)

Рецензент - проф. О.І. Волошин
Buk. Med. Herald. - 2013. - Vol. 17, № 2 (66). - P. 101-104

Надійшла до редакції 21.03.2013 року

\section{(C) І.А. Плеш, Л.І. Гайдич, 2013 \\ УДК 611.367 .013 \\ C.I. Рябий \\ МОРФОЛОГІЧНІ ПЕРЕДУМОВИ ВИНИКНЕННЯ ПРИРОДЖЕНИХ ВАД СПІЛЬНОЇ ЖОВЧНОЇ ПРОТОКИ У ПРЕНАТАЛЬНОМУ ОНТОГЕНЕЗІ}

Буковинський державний медичний університет, м. Чернівці

Резюме. Досліджено особливості пренатального морфогенезу спільної жовчної протоки на 68 серіях послідовних гістологічних зрізів зародків і передплодів та 50 трупах плодів людини за допомогою методів мікроскопії, морфометрії, макро- і мікропрепарування. Встановлено, що стадія ембріональної оклюзії упродовж 6-8-

Вступ. Природжені вади жовчних проток становлять близько 6-8 \% від усіх вад розвитку $[1,3]$. Найбільша кількість вад виявляється в ділянці спільної жовчної протоки (СЖП). Основними типами природжених вад СЖП є: природжена відсутність протоки (агенезія, аплазія), відсутність іiі просвіту (атрезія), розширення іiі просвіту в певній ділянці (кістозна дилатація) тощо. Нині відсутня єдина думка щодо механізмів формування вад жовчних проток. Відомо ряд теорій (порушення реканалізації, внутрішньоутробного запалення, “судинної катастрофи”), які намагаються пояснити виникнення вад біліарної системи в людини [1]. Зважаючи на вищенаведене, дослідження особливостей пренатального морфогенезу СЖП у людини є актуальним для виявлення морфологічних передумов можливого виникнення iї природжених вад.

Мета дослідження. 3'ясувати морфологічні передумови можливого виникнення природжених вад спільної жовчної протоки. го тижнів та дивертикулоподібна дилатація на початку 4-го місяця внутрішньоутробного розвитку можуть бути морфологічними передумовами виникнення природженої атрезії та кіст спільної жовчної протоки.

Ключові слова: спільна жовчна протока, природжені вади.

Матеріал і методи. Дослідження проведене на 68 серіях послідовних гістологічних зрізів зародків і передплодів та 50 трупах плодів людини за допомогою методів мікроскопії, морфометрії, макро-мікропрепарування. Періоди внутрішньоутробного розвитку (ВУР) систематизовані за класифікацією Г.А. Шмідта (1968).

Результати дослідження та їх обговорення. Встановлено, що ембріональний розвиток СЖП характеризується наявністю солідної стадії, яка виявляється упродовж 6-7-го тижнів ВУР. Так, у зародків 8,5-11,0 мм тім'яно-куприкової довжини (ТКД) стінки СЖП утворені двома рядами високого циліндричного епітелію 225,0-250,0 мкм завдовжки i 40,0-75,0 мкм завширшки. Просвіт у протоці заповнений скупченням епітеліальних клітин, що утворюють своєрідну епітеліальну пробку в місці $3^{6}$ єднання з протокою підшлункової залози (рис. 1).

Повна реканалізація просвіту СЖП відбувається наприкінці 8-го тижня ВУР. Так, у перед- 


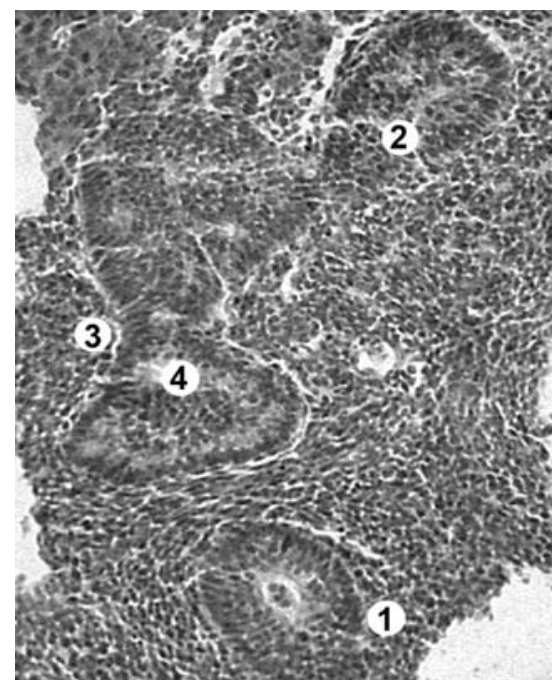

Рис. 1. Сагітальний зріз зародка людини 8,5 мм ТКД. Гематоксилін-еозин. Мікрофото. Об.×40 ок. $\times 7$

1 - дванадцятипала кишка; 2 - зачаток жовчного міхура; 3 - зачаток спільної жовчної протоки; 4 - епітеліальна пробка

плодів 21,0-24,0 мм ТКД у місці з“єднання СЖП і головної протоки підшлункової залози виявлене розширення просвіту у вигляді печінковопідшлункової ампули (ППА), яка з“єднується 3 просвітом дванадцятипалої кишки (ДПК). Порушення реканалізації просвіту, як зауважують ряд авторів [2, 5], призводить до персистування ембріональної оклюзії протоки, що може бути морфологічною передумовою для формування іiї природженої атрезії.

На початку 4-го місяця ВУР топографічно у СЖП можна розрізнити три відділи: ретродуоденальний, панкреатичний та інтрамуральний. Стінка протоки складається з одного ряду призматичного епітелію, оточеного поздовжніми пучками гладеньком'язових клітин. У плодів 82,0 мм ТКД у ділянці панкреатичного відділу СЖП виявлені дивертикулоподібні випини епітелію у прилеглий м'язовий шар іiі стінки у вигляді сліпих кишень розмірами 40,0-100,0 мкм у діаметрі (рис. 2). Останні виникають внаслідок нерівномірного росту стінки протоки і при поєднанні їх із різними факторами, що перешкоджають нормальному відтоку жовчі у ДПК, можуть бути морфологічною передумовою розвитку природженого кістозного розширення СЖП [4].

Таким чином, пренатальний морфогенез СЖП - складний процес іiі просторово-часової організації, який відбувається нерівномірно 3 чергуванням періодів прискореного та уповільненого росту. Виявлені структурні перетворення СЖП дозволяють виділити кілька критичних періодів іiі розвитку. Термін з 6-го по 8-й тижні ВУР (стадія ембріональної оклюзії) вважаємо критич-

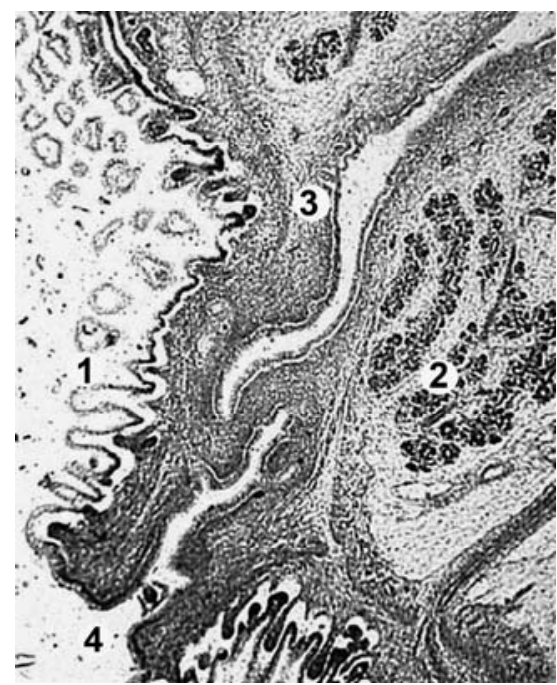

Рис. 2. Фронтальний зріз плода 82,0 мм ТКД. Борний кармін. Мікрофото. Об. $\times 8$ ок. $\times 7$

1 - дванадцятипала кишка; 2 - підшлункова залоза; 3 спільна жовчна протока; 4 - великий сосочок дванадцятипалої кишки

ним періодом для можливого виникнення природженої атрезії СЖП, а початок 4-го місяця ВУР (стадія дивертикулоподібної дилатації) - критичний період для можливого виникнення природжених кіст СЖП.

\section{Висновок}

Стадія ембріональної оклюзії спільної жовчної протоки упродовж 6-8-го тижнів пренатального онтогенезу та іiі дивертикулоподібна дилатація на початку 4-го місяця внутрішньоутробного розвитку $є$ морфологічними передумовами виникнення природженої атрезії і кіст протоки.

Перспективи подальших досліджень. Доцільно дослідити варіанти анатомічної мінливості спільної жовчної протоки в новонароджених людини.

\section{Література}

1. Нариси перинатальної анатомії / [Ахтемійчук Ю.Т., Слободян О.М., Хмара Т.В. та ін.]; за ред. Ю.Т. Ахтемійчука. - Чернівці: БДМУ, 2011. - 300 с.

2. Пикалюк В.С. Онто-, філогенез органів і систем / В.С. Пикалюк, А.Ю. Османов. - Сімферополь, 2011. $312 \mathrm{c}$.

3. Anatomical variations and congenital anomalies of extra hepatic biliary system encountered during laparoscopic cholecystectomy / K.A. Talpur, A.A. Laghari, S.A. Yousfani [et al.] // J. Pak. Med. Assoc. - 2010. - Vol. 60, № 2. - P. 89-93.

4. Karaliotas C.C. Liver and Biliary Tract Surgery: Embryological Anatomy to 3D-Imaging and Transplant Innovations / C.C. Karaliotas, C.E. Broelsch, N.A. Habib. Springer Wien New York, 2006. - 638 p.

5. Mortelé K.J. Multimodality Imaging of Pancreatic and Biliary Congenital Anomalies / K.J. Mortelé, T.C. Rocha, J.L. Streeter // RadioGraphics. - 2006. - Vol. 26. P. 715-731. 


\section{МОРФОЛОГИЧЕСКИЕ ПРЕДУСЛОВИЯ ВОЗНИКНОВЕНИЯ ВРОЖДЕННЫХ ПОРОКОВ ОБЩЕГО ЖЕЛЧНОГО ПРОТОКА В ПРЕНАТАЛЬНОМ ОНТОГЕНЕЗЕ}

\section{С.И. Рябой}

Резюме. Исследованы особенности пренатального морфогенеза общего желчного протока на 68 сериях последовательных гистологических срезов зародышей, предплодов и 50 трупах плодов человека с помощью методов микроскопии, морфометрии, макро- и микропрепарирования. Установлено, что стадия эмбриональной окклюзии в течение 6-8-й недели и дивертикулообразная дилатация в начале 4-го месяца внутриутробного развития могут быть морфологическими предусловиями возникновения врожденной атрезии и кист общего желчного протока.

Ключевые слова: общий желчный проток, врожденные пороки.

\section{MORPHOLOGIC PRECONDITIONS OF THE ONSET OF CONGENITAL DEFECTS OF THE COMMON BILE DUCT IN PRENATAL ONTOGENESIS}

\section{S.I. Riabyi}

Abstract. The peculiarities of prenatal morphogenesis of the common bile duct has been studied on 68 series of sequential histologic sections of human embryos and prefetuses and 50 cadavers of human fetuses by means of the methods of microscopy, morphometry, macroscopic and microscopic preparation. It has been established that the stage of embryonal occlusion during the $6^{\text {th }}-8^{\text {th }}$ weeks and the diverticulum-like dilatation at the beginning of the $4^{\text {th }}$ month of the intrauterine development can be morphologic preconditions of the onset of congenital atresia and cysts of the common bile duct.

Key words: common bile duct, congenital defects.

Bukovinian State Medical University (Chernivtsi)

Рецензент - проф. О.М. Слободян

Buk. Med. Herald. - 2013. - Vol. 17, № 2 (66). - P. 104-106

Надійшла до редакції 05.02.2013 року

(C) С.І. Рябий, 2013

УДК 616.248-008.61-08-053.5

\section{C.I. Сажин}

\section{ВПЛИВ БАЗИСНОЇ ТЕРАПІЇ БРОНХІАЛЬНОЇ АСТМИ НА ДИНАМІКУ НЕСПЕЦИФІЧНОЇ ГІПЕРСПРИЙНЯТЛИВОСТІ ДИХАЛЬНИХ ШЛЯХІВ У ДІТЕЙ ШКІЛЬНОГО ВІКУ ЗАЛЕЖНО ВІД ТЕРМІНУ ДЕБЮТУ ЗАХВОРЮВАННЯ}

Буковинський державний медичний університет, м. Чернівці

Резюме. У роботі проведений аналіз змін гіперсприйнятливості дихальних шляхів на тлі протизапального лікування у дітей із різними фенотипами початку бронхіальної астми. Установлено, що пацієнтам із фенотипом раннього початку захворювання притаманне

Вступ. Бронхіальна астма (БА) розглядається як хронічне алергічне запальне захворювання дихальних шляхів, що зумовлене розвитком бронхіальної гіперсприйнятливості та клінічно проявляється нападами ядухи та експіраторної задишки [4]. Гіперсприйнятливість дихальних шляхів (ГСДШ) - це стан, що характеризується підвищеною реакцією бронхіального дерева на різноманітні стимули, які призводять до обструкції бронхів при такій силі впливу, що не викликає подібної реакції в більшості здорових осіб $[1,6]$.

Неоднорідність відповіді на базисне лікування клінічно-анамнестичних ознак свідчить на користь існування окремих фенотипів БА. Кожен зростання показників гіперсприйнятливості бронхів до непрямих провокаційних чинників.

Ключові слова: бронхіальна астма, діти, гіперсприйнятливість дихальних шляхів.

окремий фенотип містить певну сукупність ознак, що дозволяє прогнозувати тяжкість перебігу захворювання, досягнення контролю над симптомами, а також визначати наявність ризику загострення [5, 8].

Остаточно нез'ясованою залишається дослідження динаміки змін ГСДШ на тлі протизапального базисного лікування у дітей, хворих на БА, залежно від фенотипу початку захворювання.

Мета дослідження. Вивчити показники неспецифічної гіперсприйнятливості бронхів із використанням непрямих (тест із дозованим фізичним навантаженням та інгаляцією $\beta_{2}$-адреноміметика) бронхопровокаційних чинників у дітей 